\title{
Do University Students Base Decisions to Engage in Sustainable Energy Behaviors on Affective or Cognitive Attitudes?
}

\author{
Piyapong Janmaimool (D) and Jaruwan Chontanawat *(D)
}

Citation: Janmaimool, P.;

Chontanawat, J. Do University

Students Base Decisions to Engage in Sustainable Energy Behaviors on Affective or Cognitive

Attitudes? Sustainability 2021, 13, 10883. https://doi.org/10.3390/ su131910883

Academic Editor: Elena Cristina Rada

Received: 26 July 2021

Accepted: 27 September 2021

Published: 30 September 2021

Publisher's Note: MDPI stays neutral with regard to jurisdictional claims in published maps and institutional affiliations.

Copyright: (c) 2021 by the authors. Licensee MDPI, Basel, Switzerland. This article is an open access article distributed under the terms and conditions of the Creative Commons Attribution (CC BY) license (https:// creativecommons.org/licenses/by/ $4.0 /)$.
Department of Social Sciences and Humanities, School of Liberal Arts, King Mongkut's University of Technology Thonburi, 126 Prachauthit Road, Thungkru District, Bangkok 10140, Thailand; Piyapong.jan@kmutt.ac.th

* Correspondence: Jaruwan.cho@kmutt.ac.th

\begin{abstract}
It is essential to understand the determinants of university students' decisions to engage in sustainable energy behaviors, as this understanding has implications for the development of communication and education strategies to promote sustainable energy behaviors. The present study aims to investigate the impacts of affective and cognitive factors on sustainable energy behaviors among university students. It will explore the affective factors of self-responsibility and social norms and the cognitive factors of environmental concerns, perceived self-efficacy, perceived self-benefits, and action knowledge about sustainable energy behaviors. A simple random technique was used to select participants from undergraduate students at King Mongkut's University of Technology Thonburi (KMUTT) in Bangkok, Thailand. Questionnaire surveys were completed by 426 participants in May and June 2020. Multiple regression analyses were used to test the ability of affective and cognitive variables to predict university students' participation in sustainable energy behaviors. The results revealed that participation in sustainable energy behaviors was significantly impacted by the perceived benefit of sustainable energy behaviors, students' concerns about climate change, perceived self-efficacy, and social norms; self-responsibility and action knowledge had no significant impact. These findings indicate that communication that focuses on climate change and approaches that enhance students' self-efficacy and the perceived benefits of sustainable energy behaviors could help promote such behaviors among university students. The sustainable energy behaviors of other social groups, including students' family members and colleagues and the general public, are also influential as they can motivate students to change their behavior.
\end{abstract}

Keywords: sustainable energy behaviors; self-responsibility; environmental concerns; social norms; self-efficacy; perceived self-benefit

\section{Introduction}

Energy plays an important role in driving economic and social development and enhancing quality of life in all countries [1]. However, the massive use of energy and the emission of greenhouse gases due to energy production and consumption play a role in climate change, which is now a global environmental crisis. Since the beginning of the 21st century, total global greenhouse gas emissions have risen steadily, due in large part to increasing $\mathrm{CO}_{2}$ emissions [2]. In the United States, transportation and electricity generation significantly contributed to a two percent increase in greenhouse gas emissions from 1990 to 2019 [3]. Similarly, in Europe, one-third of greenhouse gas emissions over the same period were due to the energy consumption and transportation of private households [4]. Moreover, population growth and economic development have exacerbated climate change due to related increases in energy demand [5,6]. The Intergovernmental Panel on Climate Change (IPCC) [7] demonstrates that global climate change has diverse negative effects on human health, economic prospects, and ecosystems. Devastating climate-related events, 
such as extreme weather, flooding, and a decrease in the global food supply, have been occurring more and more frequently [7].

In Thailand, from 2000 to 2020, total energy consumption in a number of sectors, including transportation, industry, household use and agriculture, rose by $78.3 \%$ [8]. In 2017 , the energy sector accounted for approximately $71.6 \%$ of overall greenhouse gas emissions in Thailand [9]. This is clearly a high percentage. Moreover, from 2010 to 2017, the energy sector's contribution to greenhouse gas emissions increased by $5.4 \%$. The Department of Alternative Energy Development and Efficiency (DEDE) [10] found that approximately $23 \%$ percent of the total electricity consumption in Thailand in 2017 was from by the residential sector, and this proportion is increasing. From 2011 to 2017, electricity demand in the residential sector increased from 32,799.46 GWh to 44,373.96 GWh, an increase of approximately 5.2\% per year [8]. A survey by Poolsawat et al. [11] finds that in Thailand, many electrical appliances in household consume a great amount of electricity. These inefficient appliances include air conditioners, water heaters, computers, clothes irons, and refrigerators. Poolsawat et al. [11] also find that electricity consumption could be reduced by approximately $13.7 \%$ if households switched to energy-efficient appliances. Dubois et al. [12] state that using heating is one of energy use behaviors that greatly contributes to household footprints in high-income European countries.

Population and economic growth, combined with current energy consumption behavior patterns, could greatly increase the demand for energy in the residential sector. This could further exacerbate both global climate change and future energy scarcity. It is essential, therefore, to encourage individuals in the residential sector to engage in sustainable energy behaviors (SEBs). Several scholars affirm that individual energy consumption behaviors must change to mitigate climate change and environmental decline [13,14]. For instance, Steg [15] finds that individuals' active participation in SEBs leads to reduced $\mathrm{CO}_{2}$ emissions. SEBs include using energy-efficient appliances, implementing energyefficient measures in buildings, adopting renewable energy sources and technologies, and participating in energy reduction behaviors [16]. To promote active participation in SEBs, various factors need to be explored because people have different attitudes, beliefs, and levels of readiness to participate in such behaviors. Relevant theories and previous studies indicate some factors that may influence pro-environmental behaviors (PEBs); these include environmental knowledge [17-19] attitudes towards SEBs [20], attitudes towards the environment [21,22], social norms [20], and personal norms [23], as well as socio-economic characteristics such as gender [24], age [25,26], income [27], and education level [28].

The present study explores the determinants of SEBs among university students, which may differ from those of other types of pro-environmental behaviors. Some electricitysaving behaviors in a household, or SEBs, require specific knowledge and efforts. Some of these behaviors are complex and may impact a person's daily comfort and convenience levels. The present study focuses on individual factors that affect SEBs because, once the determinants of these sustainable practices have been identified, this information can be used to motivate behavioral changes in various ways. Individual cognitive and affective factors may impact individual sustainable behaviors. Cognitive factors refer to ideas, beliefs, and information; they facilitate an individual's rational thought processes [29]. Cognitive factors that may impact sustainable behaviors include environmental awareness or concerns [28,30,31], perceived behavioral control [32,33], and environmental knowledge [31]. Affective factors are individual feelings or emotions that may drive individual motivation to engage in SEBs. Affective factors include environmental responsibility $[34,35]$ and social norms [36].

Many previous studies have explored determinants of PEBs among university students [37-39]. This current study emphasizes determinants of university students' SEBs which some types of SEBs influence individuals' comfort and convenience. Currently, no studies have yet compared the predictive power of affective and cognitive factors which influence university students' participation in SEBs. Understanding the differences among these factors can help researchers to develop effective communication strategies and educa- 
tion programs to promote SEBs among university students. In this way, the present study aims to examine the impact of cognitive and affective factors on individual participation in SEBs. A sample of university students at King Mongkut's University of Technology Thonburi in Bangkok, Thailand, were selected as participants. University students are well educated and have access to environmental knowledge; thus, they are likely to actively participate in SEBs.

\section{Literature Review}

\subsection{SEBS}

SEB are behaviors that lead to reduced or more efficient energy use or the adoption of renewable energy [40]. Reducing energy use and $\mathrm{CO}_{2}$ emissions are the primary goals of SEBs. Individuals can participate in SEBs in various ways. However, Steg et al. [40] find that adopting energy-efficient technology reduces energy use and $\mathrm{CO}_{2}$ emissions more effectively than individual behavior changes. In the residential sector, most SEBs involve reducing electricity use. According to Steg et al. [16], switching to energy-efficient appliances can significantly reduce a household's energy consumption. In addition, individuals may change or adjust their energy consumption behaviors by, for example, reducing the length of showers, turning off lights, and unplugging appliances. Huber [41] proposes that individuals can reduce their energy consumption by avoiding high-energy activities, such as drying laundry in a machine and heating water in the summer. Some behavioral changes can be implemented immediately, such as turning off lights and unplugging appliances. Some behavioral changes require time and money, such as household retrofits and implementing new, energy-efficient technology.

\subsection{Cognitive Factors}

Cognitive factors facilitate an individual's rational thought processes around the decision to engage in SEBs. Knowledge of energy saving activities is an important factor that can enhance an individual's ability to engage in SEBs. As indicated in many previous studies, environmental knowledge may have both direct and indirect impacts on PEBs. There are several types of knowledge such as environmental problem issues, ecological and environmental systems, causes of environmental problems, and environmental related actions. Different kinds of environmental knowledge have different ways of influencing PEBs [42]. Many kinds of environmental knowledge might be a precondition for PEBs, but they may not be a significant facilitator of the behaviors by themselves. However, many studies have revealed that action knowledge could have a direct impact on PEBs $[43,44]$. Furthermore, a lack of action knowledge can be a major obstacle to an individual's ability to perform PEBs.

Regarding knowledge about SEBs, Attari et al. [45] find that many people still have misconceptions about SEBs; for example, many people think that curtailment behaviors such as turning off the lights save more energy than using energy-efficient appliances. Many people still have limited knowledge of SEBs, which hinders their participation in SEBs. For instance, many people think that the amount of electricity used by appliances that are frequently used will be higher than the amount of electricity used by appliances that are rarely used [46]. Lesic et al. [47] conclude that many people use their own experience to judge how each appliance or behavior would consume or save energy. Some scholars have found that higher levels of action knowledge can increase participation in PEBs and SEBs $[19,48,49]$, but some scholars have found no significant relationship between these factors [50,51]. Regarding a study on SEBs among university students, Syaiful et al. [52] find that university students' energy saving behaviors are significantly impacted by action knowledge about energy saving practices.

Besides action knowledge, individuals' decisions to participate in SEBs can be influenced by environmental concerns. Steg et al. [40] find that increased awareness of the negative impact of one's actions on the environment may cause people to avoid specific behaviors. In this way, people who are concerned about environmental problems 
and who connect these problems to their own behaviors can decide to take part in SEBs. $\mathrm{O}^{\prime}$ Connor et al. [53] find that people who are concerned about the environment have positive attitudes towards pro-environmental behaviors. Consequently, those people may decide to engage in pro-environmental behaviors. Several studies have also found that people who have personally experienced the consequences of climate change and who are concerned about it are more motivated to engage in SEBs [54,55]. In contrast, some studies have found that concerns about the environment do not significantly impact PEBs [56,57]. Similarly, Handoyo et al. [39] have also revealed that university students' participation in PEBs are not significantly contributed by environmental concerns.

Perceived self-efficacy is an important factor in many areas that has been investigated in many studies. However, its power to predict pro-environmental behaviors could differ from case to case or group to group. According to the Theory of Planned Behavior (TPB) [20,32], people are more likely to engage in a certain behavior if they have behavioral control, which refers to a person's level of comfort with a particular behavior. According to Ajzen [32], behavioral control is one's perception of the availability of the needed resources and opportunities to engage in a particular action. Perceived behavioral control is also impacted by self-efficacy [40], which Bandura [58] defines as a person's perceived ability to perform a certain behavior. Heath and Gifford [59] and Kellstedt et al. [60] find that individuals with higher self-efficacy are more likely to engage in pro-environmental behaviors. In the case of university students, many studies also find that perceived self-efficacy significantly influences PEBs [37,38].

The perceived benefits of SEBs are another cognitive factor that may impact SEBs. Different types of SEBs require different degrees of effort and ability. Some SEBs are costly, and some require significant effort. People evaluate the value of SEBs by comparing the costs and benefits of a behavior [61]. Steg et al. [40] find that people prefer to engage in SEBs with lower costs and higher individual benefits. The benefits of SEBs can involve money or convenience [40]. For example, Harland et al. [62] find that people are more likely to use energy-efficient light bulbs when they realize that this behavior is more favorable.

\subsection{Affective Factors}

Affective factors are related to an individual's values, which can drive behavioral changes. People may decide to engage in pro-environmental behaviors primarily because of their values. Schwartz [63] finds that people who recognize the impacts of pro-environmental behaviors beyond their own self-interest are more likely to engage in these behaviors. Perceived self-responsibility for protecting the environment is therefore considered one potential predictor of pro-environmental behaviors. Self-responsibility refers to an individual's feeling of moral obligation to perform certain behaviors. According to Value-Belief-Norm Theory (VBN) [64], self-responsibility for protecting the environment is based on a person's perception of the value of the environment. The more value a person places on the environment, the more they feel responsible for protecting it. Bolderdijk et al. [65] also find that engagement in SEBs is influenced by moral considerations related to environmental values. Similarly, the study of Yusliza et al. [37] finds that self-responsibility significantly influences university students' participation in PEBs including electricity-saving behaviors.

Social norms are another factor that may impact SEBs, because individuals engage in SEBs based not only on individual interest, but also on social pressure. Therefore, individuals may decide to engage in pro-environmental behaviors due to their perceptions of the social acceptance of particular behaviors. According to the TPB [20,32], social norms significantly impact behavioral intention, which, in turn, leads to behaviors. Nolan et al. [66] report that people are more likely to engage in pro-environmental behaviors when they see that those behaviors are accepted by the general public. Stokes et al. [36] find that people with a sense of courtesy and perceived self-responsibility for protecting the environment are more likely to engage in pro-environmental behaviors. The study of Goto et al. [67] 
reveals that social norm plays an important role in promoting energy saving behaviors among university students in Vietnam.

Besides the cognitive and affective factors which possibly influence individuals' participation in PEBs and SEBs, many previous studies also explored roles of socio-demographic factors in predicting PEBs and SEBs, such as education $[42,68,69]$, gender $[42,68]$ income $[42,70]$, and age $[42,68,71]$. However, this study intends to explore only factors related to individuals' cognitive and affective decisions so that appropriate education strategies to promote SEBs among university students can be proposed. By understanding the impacts of affective and cognitive factors on sustainable energy behaviors among university students, instructors or educators can decide which pieces of information should be integrated in learning and teaching activities.

\section{Theoretical Framework}

The purpose of this study is to examine whether cognitive and affective factors can predict the SEBs of university students (See Figure 1). SEBs in this study are defined as household energy-saving behaviors that university students can engage in. They include using energy-efficient appliances, curtailment behaviors, such as turning off lights and air conditioners when not in use, efficient use of electricity, such as cleaning electrical appliances to improve their efficiency, and avoidance activities, such as not using hot water for showers in the summer and not using air conditioners in the winter. The independent variables in the study are cognitive factors, including environmental concerns, perceived self-benefits, perceived self-efficacy, and level of action knowledge.

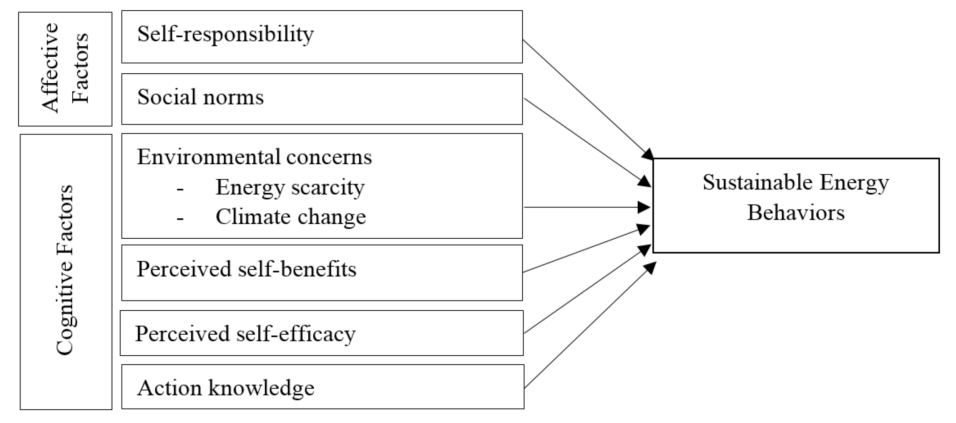

Figure 1. Conceptual framework of the study.

Environmental concerns refer to an individual's awareness of the connection between energy usage and environmental problems, such as climate change and energy scarcity. Environmental concerns can enable people to recognize the urgency of taking appropriate actions to reduce environmental problems. Additionally, environmental concerns may contribute to people's perceived individual risks associated with environmental problems, which in turn contribute to their motivation to perform environmentally friendly actions. In another aspect, many scholars believe that participation in PEBs can be based on moral judgement $[30,72]$. When people are concerned about the environmental impacts caused by their own practices, they might feel guilt for destroying the environment [73]. In this study, it is expected that people with high levels of environmental concern are more likely to engage in SEBs [53-55].

Perceived self-benefits refer to expected individual benefits from participation in SEBs, which may involve reduced costs or greater convenience. For instance, energy-saving behaviors could reduce monthly energy costs. In addition, energy-efficient appliances are available in many stores and can be easily and conveniently serviced if they break. According to the Attitude-Behavior-Context theory [64], situational factors, such as monetary incentives, legal support, or available infrastructures or services, to support adoption of PEBs can directly influence people's decision to participate in PEBs. These situational factors contribute to people's convenience or monetary benefits which potentially encourage 
the participation in PEBs. Therefore, it is expected that higher perceived benefits would lead to higher levels of participation in SEBs [40,61].

Perceived self-efficacy refers to an individual's perceived capability to engage in SEBs [51]. A lack of self-efficacy can limit participation in SEBs. According to TPB [20], perceived self-efficacy could affect perceived behavioral control, which, in turn, determines one's decision to participate in PEBs. Therefore, it is expected that people with high perceived self-efficacy are more likely to participate in SEBs $[59,60]$.

The level of action knowledge refers to an individual's action knowledge about SEBs. In fact, there are diverse kinds of knowledge related to energy issues such as energy related problems or sources of renewable energy. However, when it comes to the decision to participate in SEBs, action knowledge is important [42]. Regarding the action knowledge about SEBs, there are many different household SEBs in household, and some types of SEBs are complex. Previous studies have revealed that levels of knowledge about electricity saving could directly predict one's decision to participate in energy saving behaviors $[74,75]$. Lack of energy saving knowledge can hinder individuals' abilities to adopt SEBs [62]. Some types of SEB participation require specific skills and knowledge such as the management of electricity use and the maintenance of electrical appliances. Thus, people who possess action knowledge are likely to perform SEBs. It is expected that people with higher levels of action knowledge about SEBs are more likely to engage in SEBs [48,49].

This study also explores the role of two affective factors, self-responsibility and social norms, in driving SEBs. An individual's decision to participate in SEBs may be based on perceived values, particularly social and environmental values. A high perception of the environmental value of SEBs can increase self-responsibility, while a high perception of the social value of SEBs can motivate individuals to adhere to social norms around SEBs. Schwartz [63] proposes the Norm-Activation Model, which indicates that one's selfresponsibility relatively influences personal norms, which, in turn, affect moral behaviors. Similarly, VBN theory [64] also indicates that self-responsibility affected by perceived environmental values can directly influence PEBs. TPB [20,32] emphasizes the role of social norms in predicting one's behavioral intention, which could finally lead to actual behaviors. Therefore, it is expected that people with high self-responsibility for protecting the environment [63-65] and those with high perceptions of pro-environmental social norms $[20,32,66]$ are more likely to participate in SEBs.

\section{Methods}

\subsection{Research Tools}

A questionnaire was used to collect data. Self-reports were used to measure the dependent variable, participation in SEBs [76]. The participants were asked about the frequency with which they engage in each type of SEB; responses used a five-point Likert scale ranging from 1, "never" to 5, "always" [77]. To measure the independent variables, including environmental concerns, perceived self-efficacy, perceived self-benefits, action knowledge, self-responsibility, and social norms, questions were developed based on the relevant theories and concepts.

Regarding environmental concerns, Franzen and Meyer [78] define this term as individuals' awareness of the contribution of resource overuse to environmental degradation and related problems. This study applied the definition of Franzen and Meyer [78] to define environmental concerns in the energy context as an individual's awareness of the connection between energy usage and environmental problems such as climate change and energy scarcity. In measuring participants' environmental concerns, participants were asked to indicate how aware they were of environmental problems caused by energy usage behaviors.

Using the definition of Bandura [58], perceived self-efficacy related to SEBs was defined as the belief that one is able to perform SEBs. Questionnaires for measuring perceived self-efficacy were adapted from Chen et al. [79]. Perceived benefit in this study was defined as expected individual benefits from participation in SEBs, which may involve 
reduced costs or greater convenience $[40,61]$. Participants were asked whether they were concerned about these types of benefits when they were deciding to perform SEBs.

For measuring action knowledge, participants' self-reported knowledge of energysaving actions was employed [42]. Participants were asked to indicate whether they are aware of sustainable energy practices. In measuring participants' self-responsibility, the participants were asked to indicate their feelings of responsibility to perform SEBs. The questions were adapted from Garling et al. [80]. For the measurement of social norms, the measurement aimed to measure the influence of other people' practices on the participants' decision to engage in SEBs. The questionnaires were adapted from Lo et al. [81].

Table 1 shows the types of questions used to measure all the variables. The developed questionnaire was tested to confirm its validity and reliability. Content validity was tested using the face validity technique. Next, reliability was tested with a sample of thirty undergraduate students who were not included in the final study. The internal consistency of the scales were tested using Cronbach's alpha. Cronbach's alpha for the entire questionnaire was greater than 0.70 , indicating that the items are reliable.

Table 1. Sample questionnaire questions.

\begin{tabular}{|c|c|c|}
\hline Variables & Questions & Response Categories \\
\hline $\begin{array}{l}\text { 1. Sustainable Energy } \\
\text { Behaviors } \\
\text { (dependent variable) }\end{array}$ & $\begin{array}{l}\text { 1. I usually use energy-efficient appliances. } \\
\text { 2. I always unplug electrical appliances when I am not using them. } \\
\text { 3. In the summer, I avoid showering in hot water. } \\
\text { 4. I switch off the air condition if I'm not using it for at least } 30 \text { min. } \\
\text { 5. If the weather is good, I do not turn on an air conditioner. } \\
\text { 6. I clean the air conditioner at least once a month. } \\
\text { 7. I avoid completely filling the refrigerator. } \\
\text { 8. I switch off the lights when no one is using the room. } \\
\text { 9. I always unplug chargers after the batteries of electrical appliances } \\
\text { are full. } \\
\text { 10. I hang my clothes to dry unless it's necessary to use a dryer. }\end{array}$ & $\begin{array}{c}5=\text { Always } \\
1=\text { Never }\end{array}$ \\
\hline 2. Self-responsibility & $\begin{array}{l}\text { I am responsible for saving electricity in my residential building, even } \\
\text { at the sacrifice of my personal comfort. } \\
\text { Although energy-efficient appliances are more expensive, I would be } \\
\text { willing to purchase energy-efficient appliances. }\end{array}$ & $\begin{array}{c}5=\text { Completely agree } \\
1=\text { Completely disagree }\end{array}$ \\
\hline 3. Social norms & $\begin{array}{l}\text { Most of my family members participate in sustainable energy } \\
\text { behaviors. } \\
\text { Most people participate in and prefer sustainable energy behaviors. } \\
\text { I think I should participate in energy-saving behaviors because most } \\
\text { people do it. }\end{array}$ & $\begin{array}{c}5=\text { Completely agree } \\
1=\text { Completely disagree }\end{array}$ \\
\hline 4. Environmental concerns & $\begin{array}{l}\text { I am aware that energy resources are scarce and that massive } \\
\text { household use of electricity contributes to this problem. } \\
\text { I am aware of global climate change, which is caused by massive } \\
\text { production and consumption of electricity. }\end{array}$ & $\begin{array}{c}5=\text { Completely agree } \\
1=\text { Completely disagree }\end{array}$ \\
\hline 5. Perceived benefits & $\begin{array}{l}\text { I participate in household energy-saving behaviors mostly to } \\
\text { save money. } \\
\text { I think energy-efficient appliances are more convenient because they } \\
\text { are widely available and easily repaired or serviced. }\end{array}$ & $\begin{array}{c}5=\text { Completely agree } \\
1=\text { Completely disagree }\end{array}$ \\
\hline 6. Perceived self-efficacy & $\begin{array}{l}\text { I can reduce the electricity used in a residential building. } \\
\text { It is not difficult for me to participate in sustainable energy behaviors. }\end{array}$ & $\begin{array}{c}5=\text { Completely agree } \\
1=\text { Completely disagree }\end{array}$ \\
\hline
\end{tabular}


Table 1. Cont.

\begin{tabular}{|c|c|c|}
\hline Variables & Questions & Response Categories \\
\hline 7. Action knowledge & $\begin{array}{l}\text { 1. Do you think that electrical appliances with eco labels help save } \\
\text { electricity? } \\
\text { 2. Do you know that regularly maintaining or checking electrical } \\
\text { appliances can help save electricity? } \\
\text { 3. Do you know it is important to consider BTU to select the right air } \\
\text { conditioner for your room? } \\
\text { can help save electricity? } \\
\text { less electricity? } \\
\text { 5. Do you know that a house that is cooled by a ventilation system uses } \\
\text { 6. Do you know that putting electrical appliances that generate heat in } \\
\text { the same room as an air conditioner decreases the energy efficiency of } \\
\text { the air conditioner? } \\
\text { 7. Do you know that placing a refrigerator fifteen centimeters from the } \\
\text { wall can help save electricity? } \\
\text { 8. Do you know that LED light bulbs consume less electricity than } \\
\text { compact fluorescent lamps? } \\
\text { 9. Do you know a house or building with a light-colored facade is } \\
\text { cooler than one with a dark-colored facade? }\end{array}$ & $\begin{array}{l}\text { Yes } \\
\text { No }\end{array}$ \\
\hline
\end{tabular}

\subsection{Participants}

The participants in this study were undergraduate students at King Mongkut's University of Technology Thonburi (KMUTT) in Bangkok, Thailand. In 2020, 11,352 undergraduate students were enrolled at the university, including 5899 male students and 5433 female students. The appropriate sample size for this study was calculated using the Yamane formula [82] with a $95.0 \%$ confidence level. This calculation indicated that approximately 386 participants were needed. Random sampling was used to select the participants. All participants were informed about the study objectives and that no negative impacts from participation were expected, and all participants provided written consent to participate before the data were collected. Questionnaires were sent to 500 undergraduate students. Of these, 442 questionnaires, or $88.4 \%$, were returned. After checking their suitability for the data analysis, sixteen questionnaires were excluded because they were incomplete; therefore, a total of 426 samples were included in the data analysis.

\subsection{Data Collection and Analysis}

This study was approved by the research ethics committee of the School of Liberal Arts, KMUTT. Data were collected from undergraduate students from May to June 2020. All collected data were statistically analyzed. First, the internal consistency of the scales used to measure the dependent and independent variables was tested by calculating Cronbach's alpha, which must greater than 0.70 . Cronbach's alpha was 0.75 , indicating that the survey data are reliable. Second, for the measurement of students' SEBs which include 10 items, Pearson correlation was performed to test convergent validity [83]. Pairwise correlations between items were examined. Correlation coefficients $<0.3$ were considered negligible, a value between $0.3-0.5$ as moderate and a value $>0.5$ as strong [83]. Items which were not significantly correlated with other items and contain low correlation coefficient values $(\mathrm{r}<0.3)$, were excluded from the calculation of students' SEBs. Then, Cronbach's alpha coefficient was calculated to assess the internal consistency reliability of the scales used for the measurement of students' SEBs. Finally, a multiple linear regression was conducted to determine whether cognitive and affective factors could predict university students' participation in SEBs. 


\section{Results}

\subsection{Demographic Characteristics}

The participants included similar proportions of male and female students: $46.9 \%$ and $53.1 \%$, respectively. Most participants were engineering students $(54.7 \%) ; 19.4 \%$ were enrolled in the School of Architecture and Media Arts, and 3.5\% were enrolled in the School of Information Technology. The largest cohort was students in their fourth year of study $(48.4 \%)$. More than half lived in their own house (56.3\%), and approximately $40 \%$ lived in a dormitory (see Table 2).

Table 2. Participant characteristics $(n=426)$.

\begin{tabular}{cccc}
\hline & Participant Characteristics & $n$ & \% \\
\hline \multirow{3}{*}{ Gender } & Male & 200 & 46.9 \\
\cline { 2 - 4 } & Female & 226 & 53.1 \\
\cline { 2 - 4 } Major & Engineer & 233 & 54.7 \\
\cline { 2 - 4 } & Sciences and Technology & 58 & 13.6 \\
\cline { 2 - 4 } & Technological Education & 37 & 8.7 \\
\cline { 2 - 4 } & Information Technology & 15 & 3.5 \\
\cline { 2 - 4 } School Year & Architecture and Media Arts & 83 & 19.4 \\
\cline { 2 - 4 } & 1st year & 105 & 24.6 \\
\cline { 2 - 4 } & 2nd year & 62 & 14.6 \\
\cline { 2 - 4 } & 3rd year & 53 & 12.4 \\
\cline { 2 - 4 } Accommodation & 4th year & 206 & 48.4 \\
\cline { 2 - 4 } & Dormitory & 161 & 37.8 \\
\cline { 2 - 4 } & Rental House & 240 & 3.3 \\
\cline { 2 - 4 } & Own House & 11 & 2.6 \\
\cline { 2 - 4 } & Relative's house & 56.3 \\
\hline
\end{tabular}

\subsection{Descriptive Statistics for the Study Variables}

Table 3 presents descriptive statistics for the study variables. The results show that most participants reported high engagement in avoidance activities related to electricity usage, such as not using a clothes dryer $(\mathrm{M}=4.68, \mathrm{SD}=0.694)$ and not using air conditioning in winter $(\mathrm{M}=4.35, \mathrm{SD}=0.811)$. Participation in curtailment behaviors, such as switching off lights $(\mathrm{M}=4.30, \mathrm{SD}=0.831)$ and air conditioners $(\mathrm{M}=4.23, \mathrm{SD}=0.949)$ when not using them was also high. Fewer participants reported efficient use of refrigerator space to save energy $(\mathrm{M}=2.59, \mathrm{SD}=1.046)$ or reduced use of hot water in summer $(\mathrm{M}=3.48, \mathrm{SD}=1.406)$.

The average score for self-responsibility was $3.94(\mathrm{SD}=0.725)$. Social norms had an average score of 3.81 ( $\mathrm{SD}=0.728$ ). Regarding environmental concerns, the average score for concerns about energy scarcity was $3.89(\mathrm{SD}=0.810)$; the average score for concerns about climate change was $4.06(\mathrm{SD}=0.829)$. Perceived benefits had an average score of $4.14(\mathrm{SD}=0.671)$. The average score for action knowledge was $7.94(\mathrm{SD}=1.477)$. 
Table 3. Descriptive statistics $(n=426)$.

\begin{tabular}{|c|c|c|c|}
\hline Variables & Indicators & Mean & SD \\
\hline \multirow{11}{*}{ Sustainable Energy Behaviors } & 1. I usually use energy-efficient appliances. & 4.19 & 0.807 \\
\hline & 2. I always unplug electrical appliances when I am not using them. & 3.82 & 0.927 \\
\hline & 3. In the summer, I avoid showering in hot water. & 3.48 & 1.406 \\
\hline & 4. I switch off the air condition if I'm not using it for at least $30 \mathrm{~min}$. & 4.23 & 0.949 \\
\hline & 5. If the weather is good, I do not turn on an air conditioner. & 4.35 & 0.811 \\
\hline & 6. I clean the air conditioner at least once a month. & 3.73 & 0.977 \\
\hline & 7. I avoid completely filling the refrigerator. & 2.59 & 1.046 \\
\hline & 8. I switch off the lights when no one is using the room. & 4.30 & 0.831 \\
\hline & $\begin{array}{l}\text { 9. I always unplug chargers after the batteries of electrical appliances } \\
\text { are full. }\end{array}$ & 3.84 & 0.985 \\
\hline & 10. I hang my clothes to dry unless it's necessary to use a dryer. & 4.68 & 0.694 \\
\hline & Average Score & 3.92 & 0.943 \\
\hline \multirow{3}{*}{ Self-responsibility } & $\begin{array}{l}\text { I am responsible for saving electricity in my residential building, } \\
\text { even at the sacrifice of my personal comfort. }\end{array}$ & 4.07 & 0.836 \\
\hline & $\begin{array}{l}\text { Although energy-efficient appliances are more expensive, I would be } \\
\text { willing to purchase energy-efficient appliances. }\end{array}$ & 3.84 & 0.932 \\
\hline & Average Score & 3.96 & 0.725 \\
\hline \multirow{4}{*}{ Social Norms } & $\begin{array}{l}\begin{array}{l}\text { Most of my family members participate in sustainable energy } \\
\text { behaviors. }\end{array} \\
\end{array}$ & 3.80 & 0.880 \\
\hline & Most people participate in and prefer sustainable energy behaviors. & 3.96 & 0.828 \\
\hline & $\begin{array}{l}\text { I think I should participate in energy-saving behaviors because most } \\
\text { people do it. }\end{array}$ & 3.68 & 1.004 \\
\hline & Average Score & 3.81 & 0.728 \\
\hline \multirow{2}{*}{ Environmental Concerns } & $\begin{array}{l}\text { I am aware that energy resources are scarce and that massive } \\
\text { household use of electricity contributes to this problem. }\end{array}$ & 3.89 & 0.810 \\
\hline & $\begin{array}{l}\text { I am aware of global climate change, which is caused by massive } \\
\text { production and consumption of electricity. }\end{array}$ & 4.06 & 0.829 \\
\hline \multirow{3}{*}{ Perceived Self-benefit } & $\begin{array}{l}\text { I participate in household energy-saving behaviors mostly to save } \\
\text { money. }\end{array}$ & 4.08 & 0.831 \\
\hline & $\begin{array}{l}\text { I think energy-efficient appliances are more convenient because they } \\
\text { are widely available and easily repaired or serviced. }\end{array}$ & 4.20 & 0.799 \\
\hline & Average Score & 4.14 & 0.671 \\
\hline \multirow{3}{*}{ Perceived Self-efficacy } & I can reduce the electricity used in a residential building. & 3.90 & 0.85 \\
\hline & It is not difficult for me to participate in sustainable energy behaviors. & 4.05 & 0.87 \\
\hline & Average Score & 3.97 & 0.86 \\
\hline Action Knowledge & Average Score of Action Knowledge * & 7.94 & 1.477 \\
\hline
\end{tabular}

\subsection{SEBS}

First, the results of the Pearson correlation analysis revealed that most of the SEB items were positively correlated with one another (see Table 4), and each item mostly had correlation coefficient values greater than 0.3 [84]. Only items 3 and 7 had correlations with other items that were mostly not statistically significant. Therefore, these items, including "In the summer, I avoid showering in hot water" and "I avoid completely filling the refrigerator" should be excluded. After these two items were excluded, the reliability test was performed. The result showed that Cronbach's alpha was 0.705 , indicating that the 
scales are reliable. All items, excluding items 3 and 7, were therefore combined to represent the dependent variable.

Table 4. Correlations among SEB items $(n=426)$.

\begin{tabular}{|c|c|c|c|c|c|c|c|c|c|c|}
\hline SEBs & 1 & 2 & 3 & 4 & 5 & 6 & 7 & 8 & 9 & 10 \\
\hline $\begin{array}{c}\text { 1. I usually use } \\
\text { energy-efficient appliances. }\end{array}$ & 1 & & & & & & & & & \\
\hline $\begin{array}{l}\text { 2. I always unplug electrical } \\
\text { appliances when I am not } \\
\text { using them. }\end{array}$ & $0.345^{* *}$ & 1 & & & & & & & & \\
\hline $\begin{array}{l}\text { 3. In the summer, I avoid } \\
\text { showering in hot water. }\end{array}$ & -0.016 & -0.051 & 1 & & & & & & & \\
\hline $\begin{array}{l}\text { 4. I switch off the air } \\
\text { condition if I'm not using it } \\
\text { for at least } 30 \mathrm{~min} \text {. }\end{array}$ & $0.306^{* *}$ & $0.369 * *$ & 0.007 & 1 & & & & & & \\
\hline $\begin{array}{l}\text { 5. If the weather is good, I } \\
\text { do not turn on an } \\
\text { air conditioner. }\end{array}$ & $0.398^{* *}$ & $0.366^{* *}$ & 0.033 & $0.320^{* *}$ & 1 & & & & & \\
\hline $\begin{array}{l}\text { 6. I clean the air conditioner } \\
\text { at least once a month. }\end{array}$ & $0.330 * *$ & $0.302 * *$ & -0.090 & $0.335^{* *}$ & $0.329 * *$ & 1 & & & & \\
\hline $\begin{array}{l}\text { 7. I avoid completely filling } \\
\text { the refrigerator. }\end{array}$ & -0.082 & -0.092 & $0.370^{* *}$ & 0.035 & 0.026 & $-0.126^{* *}$ & 1 & & & \\
\hline $\begin{array}{l}\text { 8. I switch off the lights } \\
\text { when no one is using } \\
\text { the room. }\end{array}$ & $0.303^{* *}$ & $0.392 * *$ & 0.023 & $0.333^{* *}$ & $0.321 * *$ & $0.258^{* *}$ & -0.031 & 1 & & \\
\hline $\begin{array}{l}\text { 9. I always unplug chargers } \\
\text { after the batteries of } \\
\text { electrical appliances are full. }\end{array}$ & $0.339 * *$ & $0.416^{* *}$ & -0.014 & $0.262^{* *}$ & $0.303^{* *}$ & $0.262 * *$ & -0.037 & $0.477^{* *}$ & 1 & \\
\hline $\begin{array}{l}\text { 10. I hang my clothes to dry } \\
\text { unless it's necessary to use } \\
\text { a dryer. }\end{array}$ & $0.423^{* *}$ & $0.301 * *$ & 0.074 & $0.382^{* *}$ & $0.353^{* *}$ & $0.355^{* *}$ & -0.009 & $0.355^{* *}$ & $0.309 * *$ & 1 \\
\hline
\end{tabular}

Note: ${ }^{* *} p<0.01$

\subsection{Influence of Cognitive and Affective Factors on Engagement in SEBs}

A multiple regression analysis was then performed to test whether the cognitive and affective variables could predict SEBs. First, all independent variables were included in the multiple linear regression analysis to test their significant effect on the dependent variable, the participation in SEBs. The result revealed four significant variables including social norms, concerns about climate change, perceived self-benefit, and perceived self-efficacy. Then, all significant variables were included in a multiple linear regression analysis again, and the result showed that the linear combination of the cognitive and affective variables could significantly predict participation in SEBs $(\mathrm{F}(4,421)=81.608 ; p=0.000)$ (see Table 5). The multiple correlation coefficient $(R)$ was 0.661 , and $R^{2}$ was 0.437 . This means that approximately $43.7 \%$ of the variance in participation in SEBs can be predicted by the linear combination of these four variables. The data were also checked for multicollinearity. The VIF values ranged from 1.340 to 1.726 , meaning that there was no multicollinearity problem. The result also showed that four variables could significantly predict participation in SEBs. These variables were social norms $(\beta=0.146, p<0.001)$, concerns about climate change $(\beta=0.266, p<0.001)$, perceived self-benefits $(\beta=0.288, p<0.001)$, and perceived selfefficacy $(\beta=0.147, p<0.001)$. The beta values indicate that perceived self-benefits was the most powerful variable, followed by concerns about climate change, perceived self-efficacy, and social norms. All of these variables significantly and positively influenced SEBs among 
university students. Self-responsibility and action knowledge did not significantly impact the dependent variable.

Table 5. Regression analysis for variables impacting the learning effectiveness of online classes $(n=426)$.

\begin{tabular}{|c|c|c|c|c|c|}
\hline \multicolumn{6}{|c|}{ 1st Step } \\
\hline Variable & B & SE & $\beta$ & VIF & $\mathbf{t}$ \\
\hline Self-responsibility & -0.013 & 0.03 & -0.019 & 1.502 & -0.442 \\
\hline Social norms & 0.093 & 0.029 & $0.135^{* *}$ & 1.367 & 3.21 \\
\hline $\begin{array}{l}\text { Concerns about national energy } \\
\text { scarcity }\end{array}$ & -0.03 & 0.027 & -0.048 & 1.437 & -1.128 \\
\hline Concerns about climate change & 0.157 & 0.029 & $0.260 * *$ & 1.774 & 5.443 \\
\hline Perceived self-benefit & 0.186 & 0.034 & $0.249^{* *}$ & 1.66 & 5.389 \\
\hline Perceived self-efficacy & 0.167 & 0.033 & $0.255^{* *}$ & 1.96 & 5.089 \\
\hline Action knowledge & 0.015 & 0.012 & 0.045 & 1.03 & 1.24 \\
\hline $\mathrm{R}$ & & & 0.681 & & \\
\hline $\mathrm{R}^{2}$ & & & 0.463 & & \\
\hline Adjusted $\mathrm{R}^{2}$ & & & 0.454 & & \\
\hline $\mathrm{F}$ for change in $\mathrm{R}^{2}$ & & & 51.521 & & \\
\hline \multicolumn{6}{|c|}{ 2nd Step } \\
\hline Significant Variable & B & SE & $\beta$ & VIF & $\mathbf{t}$ \\
\hline Social norms & 0.088 & 0.026 & $0.146^{* *}$ & 1.384 & 3.402 \\
\hline Concerns about climate change & 0.161 & 0.027 & $0.266^{* *}$ & 1.518 & 5.909 \\
\hline Perceived self-benefit & 0.188 & 0.031 & $0.288^{* *}$ & 1.726 & 5.984 \\
\hline Perceived self-efficacy & 0.101 & 0.029 & $0.147^{* *}$ & 1.340 & 3.465 \\
\hline $\mathrm{R}$ & & & 0.661 & & \\
\hline $\mathrm{R}^{2}$ & & & 0.437 & & \\
\hline Adjusted $\mathrm{R}^{2}$ & & & 0.431 & & \\
\hline$F$ for change in $R^{2}$ & & & 81.608 & & \\
\hline
\end{tabular}

\section{Discussion and Conclusions}

This study has examined whether cognitive and affective factors can predict university students' participation in SEBs. First, the results show the levels of participation in each type of SEBs. Most participants reported very high participation in the avoidance of highenergy activities, such as not using a tumble drier when doing laundry, and not using an air conditioner when the weather is good. They made use of weather conditions for their energy usage activities. It is possible that participants were aware of the additional expense of using those appliances, and they preferred other options which require less costs or no costs. However, there is an exceptional case insofar as many participants still reported a high level of participation in using hot water for showers in the summer. It is possible that they were used to this type of practice and did not realize the benefit brought about by avoidance of showering in hot water. The avoidance of electricity-wasting activities, such as switching off lights and air conditioning, were also highly participated in by study participants. These types of activities can be immediately practiced without requiring a lot of time and effort. However, participants reported a high level of participation in some types of electricity-wasting activities, such as not unplugging electrical appliances. Although these electricity-saving activities can be easily performed, the participants might 
have not realized the importance of these practices for energy consumption reduction. The level of participation in using energy-efficient appliances, which is considered to be an effective measure to reduce a household's energy consumption [16], was high. Participants might have some knowledge about energy-efficient appliances which could reduce both energy use and $\mathrm{CO}_{2}$ emissions [40]. Notably, when compared to the participation in other SEBs, the levels of participation in effective use of appliances (such as avoidance of completely filling the refrigerator) and maintenance of electrical appliances (such as cleaning the air conditioner at least once a month) were low. This implies that university students should be given more education about these types of SEBs.

Second, multiple regression analyses showed that three cognitive factors and one affective factor could significantly predict university students' participation in SEBs. Three cognitive factors-perceived self-benefit, concerns about climate change, perceived selfefficacy - had significantly more predictive power than the significant affective factor, social norms. This means that university students' decisions to engage in SEBs are based primarily on cognitive thought processes. Among the significant cognitive factors, perceived self-benefit was the most powerful predictor. The results showed that higher perceived convenience and financial benefits led to higher engagement in SEBs. As stated by Thøgersen [61], people evaluate the value of SEBs by comparing the costs and benefits of a behavior. Additionally, according to Attitude-Behavior-Context theory [64], some situational factors which can generate benefits from the participation in PEBs can encourage people's PEBs. Steg et al. [40] find that a better understanding of the individual benefits of SEBs increases the likelihood that individuals will engage in SEBs. Harland et al. [85] also find that people who are concerned about individual benefits are more likely to purchase energy-saving light bulbs. Similarly, Hien and Chi [86] also find that household electricity saving behaviors are strongly influenced by perceived benefits.

University students' concerns about climate change are also a strong predictor of students' participation in SEBs. This means that students who understand the impact of individual energy consumption behaviors on climate change are more likely to engage in SEBs. Rudman et al. [54] and Akerlof et al. [87] also report that promoting individual concerns about climate change could significantly increase SEBs. To promote SEBs among university students, information about climate change could be incorporated into the study curriculum. Guy et al. [88] and Tobler et al. [89] suggest that enhancing people's understating of climate change and its possible causes could increase their concern about it. In our sample, students' concerns about national energy scarcity did not significantly effect SEBs.

Notably, students' action knowledge about SEBs was also not a significant factor. This implies that students with high knowledge of SEBs may still decide not to engage in these behaviors. However, the results show that perceived self-efficacy, or an individual's perceived ability to perform SEBs, significantly predicts SEBs. This implies that providing knowledge about SEBs is not sufficient to drive behavioral change; students' perceived efficacy should also be promoted to drive behavioral change. For instance, students could be offered practical training on difficult SEBs, such as cleaning air conditioners. It should also be noted that some types of SEBs can be costly. This may also minimize students perceived self-efficacy to engage in these behaviors. Díaz et al. [90], Abraham et al. [91], and Huang [92] also report that self-efficacy significantly predicts pro-environmental behaviors. Similarly, Lee and Tanusia [93] report a significant relationship between self-efficacy and energy conservation intention, but Niehoff [94] finds no significant relationship between self-efficacy and household energy-saving behavior.

Of the affective factors studied here, only social norms were significant. This finding can be supported by TPB theory which states that social norms influence behavioral intention and lead to the behavior. However, this study found that social norms influenced students' participation in SEBs less than the cognitive variables. In contrast with this study, the study of Du and Pan [95] did not find a significant effect of social norms on PEBs of university students. 
Self-responsibility did not significantly impact SEBs. This implies that students who have positive attitudes towards the environment and feel responsible for protecting it still may not engage in household SEBs. It is possible that participation in SEBs requires more time, effort, and resources than participation in other types of PEBs; thus, it relies more on other important factors such as capability, available resources, and situational factors. This finding contradicts the Norm-Activation Model [63] and VBN theory [64] which indicate that self-responsibility can be associated with moral behaviors such as PEBs and SEBs. The study of Du and Pan [95] also reports that university students' energy saving intention, which is significantly associated with energy saving behaviors, can be greatly predicted by personal norm.

For this study, it can be suggested that benefits or outcomes from the participation in each type of SEBs should be clearly communicated to university students, particularly monetary benefit, convenience, and energy consumption reduction. This is because students' decisions to participate in SEBs are mainly based on their perceived self-benefits. In addition, universities should provide students with more specific knowledge about energy, including information about climate change and the environmental impacts of energy consumption. These pieces of information could enable students to recognize the urgency of taking actions to prevent the adverse impacts of climate change. As mentioned above, students' concerns about climate change impact their decisions to engage in SEBs. Social norms can play an important role in driving SEBs among university students. This implies that students who believe that SEBs are socially accepted may be more likely to engage in SEBs. Some scholars also find that individuals are more likely to engage in SEBs if they believe that the general public approves of SEBs [66,85]. Lee and Tanusia [93] and Lingyuna et al. [96] find that social norms can predict energy consumption behavior intention.

In conclusion, the findings show that students' decisions to participate in SEBs are primarily based on cognitive factors, which facilitate rational thought processes. Significant factors include concerns about the impact of energy behaviors on climate change, perceived self-efficacy, and perceived self-interest. To promote SEBs among university students, students should be educated about the effects of energy behaviors on climate change, about how to engage in difficult or complicated SEBs, and about the potential benefits of SEB participation. Moreover, social norms play an important role in driving behavioral change. Participation in SEBs by other university groups, such as staff and lecturers, also influence students' decisions. Therefore, SEBs should be promoted among staff and lecturers as well as students.

\section{Limitations of the Study}

There are some limitations which should be addressed. This study employed selfreporting for measuring action knowledge about sustainable energy behaviors. This may cause some biases in measuring the actual action knowledge possessed by participants. In addition, this study focused only cognitive and affective variables, whereas socio-economic characteristics of university students and basic environmental knowledge are not included in this study. It is possible that SEBs may be associated with these socio-economic variables and basic environmental knowledge. Most importantly, the majority of participants in this study were in fourth year of a bachelor's degree, and all of them were studying in the field of Sciences and Technology. Therefore, the results might not be generalizable for all university students.

Author Contributions: P.J. conceived the idea of the study. Both P.J. and J.C. carried out data collection and data analysis. Both authors have read and agreed to the published version of the manuscript.

Funding: The research was funded by King Mongkut's University of Technology Thonburi: School of Liberal Arts, grant number 2563205 and the APC was fund by the Research and Intellectual Property Promotion Centre (RIPPC). 
Institutional Review Board Statement: The study was conducted according to the guidelines of the Declaration of Helsinki, and approved by Research Ethics Committee of the School of Liberal Arts, King Mongkut's University of Technology Thonburi (SoLA-EA-2020-1-005) on 11 May 2020.

Informed Consent Statement: Informed consent was obtained from all subjects involved in the study.

Data Availability Statement: Not applicable.

Acknowledgments: The authors would like to thank the Department of Social Sciences and Humanities, School of Liberal Arts, and Research and Intellectual Property Promotion Centre (RIPPC), King Mongkut's University of Technology Thonburi, for providing the funding for this research project. The views and opinions in the paper belong to the authors and any errors or mistakes are the authors' responsibility.

Conflicts of Interest: The authors declare no conflict of interest.

\section{References}

1. Kaya, O.; Florkowski, W.J.; Us, A.; Klepacka, A.M. Renewable energy perception by rural residents of a peripheral EU region. Sustainability 2019, 11, 2075. [CrossRef]

2. European Commission. Global $\mathrm{CO}_{2}$ Emissions Continue to Rise but EU Bucks Global Trend. Available online: https://ec.europa. eu/jrc/en/news/global-co2-emissions-continue-rise-eu-bucks-global-trend (accessed on 9 September 2020).

3. United State Environmental Protection Agency (EPA). Inventory of U.S. Greenhouse Gas Emissions and Sinks 1990-2019. EPA 430-R-21-005; The Environmental Protection Agency: Washington, DC, USA, 2021; pp. 9339-9340.

4. Eurostat. Air Emissions Accounts by NACE Rev. 2 Activity. Available online: https://appsso.eurostat.ec.europa.eu/nui/show. do?dataset=env_ac_ainah_r2\&lang=en (accessed on 10 March 2021).

5. Kharas, H. The Emerging Middle Income Class in Developing Countries; Working Paper; OECD Development Centre: Paris, France, 2010.

6. Gerland, P.; Raftery, A.E.; Ševčíková, H.; Li, N.; Gu, D.; Spoorenberg, T.; Alkema, L.; Fosdick, B.K.; Chunn, J.; Lalic, N. World population stabilization unlikely this century. Science 2014, 346, 234-237. [CrossRef]

7. $\quad$ Pachauri, R.K.; Allen, M.R.; Barros, V.R.; Broome, J.; Cramer, W.; Christ, R.; Church, J.A.; Clarke, L.; Dahe, Q.; Dasgupta, P. Climate Change 2014: Synthesis Report. Contribution of Working Groups I, II and III to the Fifth Assessment Report of the Intergovernmental Panel on Climate Change; IPCC: Geneva, Switzerland, 2014.

8. Energy Policy and Planning Office (EPPO). Energy Statistics of Thailand 2020; Ministry of Energy: Bangkok, Thailand, 2020.

9. Office of Natural Resources and Environmental Policy and Planning (ONEP). Second Biennial Update Report of Thailand; Ministry of Natural Resources and Environment: Bangkok, Thailand, 2017.

10. Department of Alternative Energy Development and Efficiency (DEDE). Energy Balance of Thailand 2017; Ministry of Energy: Bangkok, Thailand, 2017.

11. Poolsawat, K.; Tachajapong, W.; Prasitwattanaseree, S.; Wongsapai, W. Electricity consumption characteristics in Thailand residential sector and its saving potential. Energy Rep. 2020, 6, 337-343. [CrossRef]

12. Dubois, G.; Sovacool, B.; Aall, C.; Nilsson, M.; Barbier, C.; Herrmann, A.; Bruyère, S.; Andersson, C.; Skold, B.; Nadaud, F. It starts at home? Climate policies targeting household consumption and behavioral decisions are key to low-carbon futures. Energy Res. Soc. Sci. 2019, 52, 144-158. [CrossRef]

13. Dietz, T.; Gardner, G.T.; Gilligan, J.; Stern, P.C.; Vandenbergh, M.P. Household actions can provide a behavioral wedge to rapidly reduce US carbon emissions. Proc. Natl. Acad. Sci. USA 2009, 106, 18452-18456. [CrossRef]

14. Pawlik, K.; Steg, L.; Sood, A. Psychological approaches and contributions to global environmental change. In World Social Science Report; OECD: Paris, France, 2013.

15. Steg, L.; Perlaviciute, G.; Van der Werff, E.; Lurvink, J. The significance of hedonic values for environmentally relevant attitudes, preferences, and actions. Environ. Behav. 2014, 46, 163-192. [CrossRef]

16. Steg, L.; Perlaviciute, G.; van der Werff, E. Understanding the human dimensions of a sustainable energy transition. Front. Psychol. 2015, 6, 805. [CrossRef] [PubMed]

17. Hadler, M.; Haller, M. Global activism and nationally driven recycling: The influence of world society and national contexts on public and private environmental behavior. Int. Sociol. 2011, 26, 315-345. [CrossRef]

18. He, Q.; Duan, Y.; Wang, R.; Fu, Z. Factors affecting consumers' purchase intention of eco-friendly food in China: The evidence from respondents in Beijing. Int. J. Consum. Stud. 2019, 43, 457-470. [CrossRef]

19. Hines, J.M.; Hungerford, H.R.; Tomera, A.N. Analysis and synthesis of research on responsible environmental behavior: A meta-analysis. J. Environ. Educ. 1987, 18, 1-8. [CrossRef]

20. Ajzen, I. From intentions to actions: A theory of planned behavior. In Action Control; Springer: Berlin/Heidelberg, Germany, 1985; pp. 11-39.

21. Blake, D.E.; Guppy, N.; Urmetzer, P. Canadian public opinion and environmental action: Evidence from British Columbia. Can. J. Political Sci. Rev. Can. Sci. Polit. 1997, 30, 451-472. [CrossRef] 
22. Oskamp, S.; Harrington, M.J.; Edwards, T.C.; Sherwood, D.L.; Okuda, S.M.; Swanson, D.C. Factors influencing household recycling behavior. Environ. Behav. 1991, 23, 494-519. [CrossRef]

23. Stern, P.C.; Dietz, T.; Abel, T.; Guagnano, G.A.; Kalof, L. A value-belief-norm theory of support for social movements: The case of environmentalism. Hum. Ecol. Rev. 1999, 6, 81-97.

24. Kollmuss, A.; Agyeman, J. Mind the gap: Why do people act environmentally and what are the barriers to pro-environmental behavior? Environ. Educ. Res. 2002, 8, 239-260. [CrossRef]

25. Mtutu, P.; Thondhlana, G. Encouraging pro-environmental behaviour: Energy use and recycling at Rhodes University, South Africa. Habitat Int. 2016, 53, 142-150. [CrossRef]

26. Lynn, P. Distinguishing Dimensions of Pro-Environmental Behaviour; ISER Working Paper Series; ISER: Essex, UK, 2014.

27. Brown, Z. Greening Household Behaviour: Cross-Domain Comparisons in Environmental Attitudes and Behaviours Using Spatial Effects; OECD: Paris, France, 2014.

28. Rivera-Torres, P. Development of pro-environmental conduct in individuals and its determinants. Rev. Esp. Investig. Sociol. 2018, 163, 59-78.

29. Berlin, N.; Tavani, J.-L.; Beasançon, M. An exploratory study of creativity, personality and schooling achievement. Educ. Econ. 2016, 24, 536-556. [CrossRef]

30. Xu, Y.; Li, W.; Chi, S. Altruism, Environmental Concerns, and Pro-environmental Behaviors of Urban Residents: A Case Study in a Typical Chinese City. Front. Psychol. 2021, 12, 643759. [CrossRef] [PubMed]

31. Schwartz, S.H. An overview of the Schwartz theory of basic values. Online Read. Psychol. Cult. 2012, 2, 1-20. [CrossRef]

32. Ajzen, I. The theory of planned behavior. Organ. Behav. Hum. Decis. Process. 1991, 50, 179-211. [CrossRef]

33. Ajzen, I.; Fishbein, M. Attitudes and the attitude-behavior relation: Reasoned and automatic processes. Eur. Rev. Soc. Psychol. 2000, 11, 1-33. [CrossRef]

34. Rahman, N.A. Knowledge, Internal, and Environmental Factors on Environmental Care Behaviour among Aboriginal Students in Malaysia. Int. J. Environ. Sci. Educ. 2016, 11, 5349-5366.

35. Wang, P.; Liu, Q.; Qi, Y. Factors influencing sustainable consumption behaviors: A survey of the rural residents in China. J. Clean. Prod. 2014, 63, 152-165. [CrossRef]

36. Stokes, L.C.; Mildenberger, M.; Savan, B.; Kolenda, B. Analyzing barriers to energy conservation in residences and offices: The Rewire program at the University of Toronto. Appl. Environ. Educ. Commun. 2012, 11, 88-98. [CrossRef]

37. Yusliza, M.Y.; Amirudin, A.; Rahadi, R.A.; Nik Sarah Athirah, N.A.; Ramayah, T.; Muhammad, Z.; Dal Mas, F.; Massaro, M.; Saputra, J.; Mokhlis, S. An investigation of pro-environmental behaviour and sustainable development in Malaysia. Sustainability 2020, 12, 7083. [CrossRef]

38. Jugert, P.; Greenaway, K.H.; Barth, M.; Büchner, R.; Eisentraut, S.; Fritsche, I. Collective efficacy increases pro-environmental intentions through increasing self-efficacy. J. Environ. Psychol. 2016, 48, 12-23. [CrossRef]

39. Handoyo, B.; Astina, I.; Mkumbachi, R. Students' environmental awareness and pro-environmental behaviour: Preliminary study of geography students at state university of malang. In Proceedings of the IOP Conference Series: Earth and Environmental Science, Jawa Tengah, Indonesia, 31 August 2019; p. 012049.

40. Steg, L.; Shwom, R.; Dietz, T. What drives energy consumers?: Engaging people in a sustainable energy transition. IEEE Power Energy Mag. 2018, 16, 20-28. [CrossRef]

41. Huber, J. Towards industrial ecology: Sustainable development as a concept of ecological modernization. J. Environ. Policy Plan. 2000, 2, 269-285. [CrossRef]

42. Vainio, A.; Pulkka, A.; Paloniemi, R.; Varho, V.; Tapio, P. Citizens' sustainable, future-oriented energy behaviours in energy transition. J. Clean. Prod. 2020, 245, 118801. [CrossRef]

43. Pohjolainen, P.; Tapio, P.; Vinnari, M.; Jokinen, P.; Räsänen, P. Consumer consciousness on meat and the environment-Exploring differences. Appetite 2016, 101, 37-45. [CrossRef] [PubMed]

44. Vainio, A.; Paloniemi, R. Does belief matter in climate change action? Public Underst. Sci. 2013, 22, 382-395. [CrossRef]

45. Attari, S.Z.; DeKay, M.L.; Davidson, C.I.; De Bruin, W.B. Public perceptions of energy consumption and savings. Proc. Natl. Acad. Sci. USA 2010, 107, 16054-16059. [CrossRef]

46. Schley, D.R.; DeKay, M.L. Cognitive accessibility in judgments of household energy consumption. J. Environ. Psychol. 2015, 43, 30-41. [CrossRef]

47. Lesic, V.; De Bruin, W.B.; Davis, M.C.; Krishnamurti, T.; Azevedo, I.M.L. Consumers' perceptions of energy use and energy savings: A literature review. Environ. Res. Lett. 2018, 13, 033004. [CrossRef]

48. Casaló, L.V.; Escario, J.-J.; Rodriguez-Sanchez, C. Analyzing differences between different types of pro-environmental behaviors: Do attitude intensity and type of knowledge matter? Resour. Conserv. Recycl. 2019, 149, 56-64. [CrossRef]

49. Frick, J.; Kaiser, F.G.; Wilson, M. Environmental knowledge and conservation behavior: Exploring prevalence and structure in a representative sample. Personal. Individ. Differ. 2004, 37, 1597-1613. [CrossRef]

50. Vicente-Molina, M.A.; Fernández-Sáinz, A.; Izagirre-Olaizola, J. Environmental knowledge and other variables affecting proenvironmental behaviour: Comparison of university students from emerging and advanced countries. J. Clean. Prod. 2013, 61, 130-138. [CrossRef]

51. Meinhold, J.L.; Malkus, A.J. Adolescent environmental behaviors: Can knowledge, attitudes, and self-efficacy make a difference? Environ. Behav. 2005, 37, 511-532. [CrossRef] 
52. Syaiful, A.Z. The Effect of Knowledge and Attitude of Student towards Save Energy Behavior in Makassar City. Ph.D. Thesis, Universitas Negeri Makassar, Makassar, Indonesia, 2016.

53. O'Connor, R.E.; Bard, R.J.; Fisher, A. Risk perceptions, general environmental beliefs, and willingness to address climate change. Risk Anal. 1999, 19, 461-471. [CrossRef]

54. Rudman, L.A.; McLean, M.C.; Bunzl, M. When truth is personally inconvenient, attitudes change: The impact of extreme weather on implicit support for green politicians and explicit climate-change beliefs. Psychol. Sci. 2013, 24, 2290-2296. [CrossRef]

55. Spence, A.; Poortinga, W.; Butler, C.; Pidgeon, N.F. Perceptions of climate change and willingness to save energy related to flood experience. Nat. Clim. Chang. 2011, 1, 46-49. [CrossRef]

56. Poortinga, W.; Fisher, S.; Bohm, G.; Steg, L.; Whitmarsh, L.; Ogunbode, C. European Attitudes to Climate Change and Energy. Topline Results from Round 8 of the European Social Survey; European Social Survey ERIC: London, UK, 2018.

57. Abrahamse, W.; Steg, L.; Vlek, C.; Rothengatter, T. A review of intervention studies aimed at household energy conservation. J. Environ. Psychol. 2005, 25, 273-291. [CrossRef]

58. Bandura, A. Social cognitive theory of self-regulation. Organ. Behav. Hum. Decis. Process. 1991, 50, 248-287. [CrossRef]

59. Heath, Y.; Gifford, R. Free-market ideology and environmental degradation: The case of belief in global climate change. Environ. Behav. 2006, 38, 48-71. [CrossRef]

60. Kellstedt, P.M.; Zahran, S.; Vedlitz, A. Personal efficacy, the information environment, and attitudes toward global warming and climate change in the United States. Risk Anal. Int. J. 2008, 28, 113-126. [CrossRef]

61. Thøgersen, J. How may consumer policy empower consumers for sustainable lifestyles? J. Consum. Policy 2005, 28, 143-177. [CrossRef]

62. Harland, P.; Staats, H.; Wilke, H.A. Situational and personality factors as direct or personal norm mediated predictors of pro-environmental behavior: Questions derived from norm-activation theory. Basic Appl. Soc. Psychol. 2007, 29, 323-334. [CrossRef]

63. Schwartz, S.H. Elicitation of moral obligation and self-sacrificing behavior: An experimental study of volunteering to be a bone marrow donor. J. Personal. Soc. Psychol. 1970, 15, 283. [CrossRef] [PubMed]

64. Stern, P. Toward a coherent theory of environmentally significant behavior. J. Soc. Issues 2000, 56, 407-424. [CrossRef]

65. Bolderdijk, J.W.; Steg, L.; Geller, E.S.; Lehman, P.; Postmes, T. Comparing the effectiveness of monetary versus moral motives in environmental campaigning. Nat. Clim. Chang. 2013, 3, 413-416. [CrossRef]

66. Nolan, J.M.; Schultz, P.W.; Cialdini, R.B.; Goldstein, N.J.; Griskevicius, V. Normative social influence is underdetected. Personal. Soc. Psychol. Bull. 2008, 34, 913-923. [CrossRef]

67. Goto, N.; Tokunaga, S.; Nga, D.T.; Thanh, V.H.T. Analysis of energy-saving behavior among university students in Vietnam. J. Environ. Sci. Eng. B 2016, 5, 355-362.

68. Thondhlana, G.; Hlatshwayo, T.N. Pro-environmental behaviour in student residences at Rhodes University, South Africa. Sustainability 2018, 10, 2746. [CrossRef]

69. Paço, A.; Lavrador, T. Environmental knowledge and attitudes and behaviours towards energy consumption. J. Environ. Manag. 2017, 197, 384-392. [CrossRef] [PubMed]

70. Zorić, J.; Hrovatin, N. Household willingness to pay for green electricity in Slovenia. Energy Policy 2012, 47, 180-187. [CrossRef]

71. Otto, S.; Kaiser, F.G. Ecological behavior across the lifespan: Why environmentalism increases as people grow older. J. Environ. Psychol. 2014, 40, 331-338. [CrossRef]

72. Eom, K.; Papadakis, V.; Sherman, D.K.; Kim, H.S. The psychology of proenvironmental support: In search of global solutions for a global problem. Curr. Dir. Psychol. Sci. 2019, 28, 490-495. [CrossRef]

73. Salequzzaman, M.; Stocker, L. The context and prospects for environmental education and environmental careers in Bangladesh Int. J. Sustain. High. Educ. 2001, 2, 104-127. [CrossRef]

74. Pothitou, M.; Hanna, R.F.; Chalvatzis, K.J. Environmental knowledge, pro-environmental behaviour and energy savings in households: An empirical study. Appl. Energy 2016, 184, 1217-1229. [CrossRef]

75. Abrahamse, W.; Steg, L.; Vlek, C.; Rothengatter, T. The effect of tailored information, goal setting, and tailored feedback on household energy use, energy-related behaviors, and behavioral antecedents. J. Environ. Psychol. 2007, 27, 265-276. [CrossRef]

76. Gatersleben, B.; Steg, L.; Vlek, C. Measurement and determinants of environmentally significant consumer behavior. Environ. Behav. 2002, 34, 335-362. [CrossRef]

77. Margai, F.L. Analyzing changes in waste reduction behavior in a low-income urban community following a public outreach program. Environ. Behav. 1997, 29, 769-792. [CrossRef]

78. Franzen, A.; Meyer, R. Environmental attitudes in cross-national perspective: A multilevel analysis of the ISSP 1993 and 2000. Eur. Sociol. Rev. 2010, 26, 219-234. [CrossRef]

79. Chen, G.; Gully, S.M.; Eden, D. Validation of a new general self-efficacy scale. Organ. Res. Methods 2001, 4, 62-83. [CrossRef]

80. Gärling, T.; Fujii, S.; Gärling, A.; Jakobsson, C. Moderating effects of social value orientation on determinants of proenvironmental behavior intention. J. Environ. Psychol. 2003, 23, 1-9. [CrossRef]

81. Lo, S.H.; Peters, G.J.Y.; Kok, G. A review of determinants of and interventions for proenvironmental behaviors in organizations. J. Appl. Soc. Psychol. 2012, 42, 2933-2967. [CrossRef]

82. Yamane, T. Statistics: An Introduction Analysis; Harper \& Row: Manhattan, NY, USA, 1973. 
83. Cohen, J. The $t$-test for means, Chapter 2. In Statistical Power Analysis for the Behavioral Sciences, 2nd ed.; Hillsdale, Lawrence Erlbaum Associates: Mahwah, NJ, USA, 1988.

84. Portney, L.G.; Watkins, M.P. Foundations of Clinical Research: Applications to Practice; Pearson/Prentice Hall: Upper Saddle River, NJ, USA, 2009; Volume 892.

85. Harland, P.; Staats, H.; Wilke, H.A. Explaining proenvironmental intention and behavior by personal norms and the Theory of Planned Behavior 1. J. Appl. Soc. Psychol. 1999, 29, 2505-2528. [CrossRef]

86. Hien, N.N.; Chi, P.H. The factors affecting household electricity saving behavior: A study in Vietnam. Int. J. Sustain. Dev. Plan. 2020, 15, 1241-1250. [CrossRef]

87. Akerlof, K.; Maibach, E.W.; Fitzgerald, D.; Cedeno, A.Y.; Neuman, A. Do people "personally experience" global warming, and if so how, and does it matter? Glob. Environ. Chang. 2013, 23, 81-91. [CrossRef]

88. Guy, S.; Kashima, Y.; Walker, I.; O’Neill, S. Investigating the effects of knowledge and ideology on climate change beliefs. Eur. J. Soc. Psychol. 2014, 44, 421-429. [CrossRef]

89. Tobler, C.; Visschers, V.H.; Siegrist, M. Consumers' knowledge about climate change. Clim. Chang. 2012, 114, 189-209. [CrossRef]

90. Díaz, M.F.; Charry, A.; Sellitti, S.; Ruzzante, M.; Enciso, K.; Burkart, S. Psychological Factors Influencing Pro-environmental Behavior in Developing Countries: Evidence From Colombian and Nicaraguan Students. Front. Psychol. 2020, 11, 580730. [CrossRef] [PubMed]

91. Abraham, J.; Pane, M.; Chairiyani, R. An investigation on cynicism and environmental self-efficacy as predictors of proenvironmental behavior. Psychology 2015, 6, 234-242. [CrossRef]

92. Huang, H. Media use, environmental beliefs, self-efficacy, and pro-environmental behavior. J. Bus. Res. 2016, 69, $2206-2212$. [CrossRef]

93. Lee, J.; Tanusia, A. Energy conservation behavioural intention: Attitudes, subjective norm and self-efficacy. In Proceedings of the IOP Conference Series: Earth and Environmental Science, Beijing, China, 19-22 August 2016; p. 012087.

94. Niehoff, E. Energy Saving within Households: How the Antecedents of Our Behaviour Influence Energy Consumption; University of Twente: Enschede, The Netherlands, 2021.

95. Du, J.; Pan, W. Examining energy saving behaviors in student dormitories using an expanded theory of planned behavior. Habitat Int. 2021, 107, 102308. [CrossRef]

96. Lingyun, M.; Rui, N.; Hualong, L.; Xiaohua, L. Empirical research of social norms affecting urban residents low carbon energy consumption behavior. Energy Procedia 2011, 5, 229-234. [CrossRef] 